\title{
O Cotidiano nos Múltiplos Espaços Contemporâneos ${ }^{1}$
}

\author{
Ana Maria Nicolaci-da-Costa ${ }^{2}$ \\ Pontifícia Universidade Católica do Rio de Janeiro
}

\begin{abstract}
RESUMO - Uma das características mais marcantes do período moderno foi a da concepção de um tempo longo, no qual eram possíveis a conquista do espaço e o planejamento do futuro. Já na contemporaneidade, a diacronia moderna dá lugar a um eterno presente. Neste presente, espaços sincrônicos se multiplicam. As novas tecnologias da informação e telecomunicação, principalmente a Internet e a telefonia celular, introduzem alterações nos espaços físicos e geram espaços alternativos a estes. Neste artigo é realizada uma revisão, forçosamente incompleta, da extensa literatura transdisciplinar sobre esses novos espaços contemporâneos e seus efeitos sobre os homens, mulheres e crianças que neles vivem.
\end{abstract}

Palavras-chave: internet; celulares; alterações no espaço físico; espaços alternativos.

\section{Daily Life in the Multiple Contemporary Spaces}

\begin{abstract}
One of the most distinctive characteristics of the modern era was the concept of an enduring length of time, during which it was possible to conquer space and make long-term plans. In the present era, the long time of modernity gave way to an ever-lasting present. In such a present, co-existing spaces multiply. New information and telecommunication technologies, mainly the Internet and mobile telephony, introduce alterations in physical spaces and generate new alternative spaces. This paper presents an inevitably incomplete review of the extensive transdisciplinary literature on these contemporary spaces and their effects on the men, women and children who inhabit them.
\end{abstract}

Key words: internet; cell phones; alterations in physical spaces; alternative spaces.

Tempo e espaço são duas categorias básicas da experiência humana. As concepções de tempo e espaço, no entanto, não são imutáveis. Estão sempre atreladas a determinadas sociedades e/ou a determinados períodos da vida social, nos quais não necessariamente têm pesos iguais (Harvey, 1989/1999).

Ao longo dos séculos, tempo e espaço estiveram intimamente associados. Espaço era aquilo que o ser humano podia atravessar com maior ou menor rapidez utilizando recursos básicos, como as próprias pernas ou as pernas de um animal, durante um determinado período de tempo. Tempo, por sua vez, era aquilo de que se necessitava para percorrer um determinado espaço fazendo uso desses mesmos recursos (Bauman, 2000/2001).

No século XIX e no início do século XX, o processo de industrialização inaugurado pela revolução industrial e o desenvolvimento de novas tecnologias (como o telégrafo, o telefone e o automóvel) levaram a uma aceleração do tempo até então inédita. A industrialização acelerou vertiginosamente o ritmo da produção outrora artesanal. O automóvel e outros meios de transporte cada vez mais rápidos reduziram o tempo necessário para qualquer deslocamento espacial antes limitado à capacidade física de seres humanos ou animais. Já uma mensagem telegrafada ou um telefonema tornaram

1 Agradeço o apoio dado pelo CNPq, sob a forma de bolsa de produtividade em pesquisa. Agradeço, também, as leituras cuidadosas das versões iniciais deste artigo feitas por Carla Faria Leitão, Daniela Romão-Dias e Rosane Abreu.

2 Endereço: Departamento de Psicologia, Rua Marquês de São Vicente, 225, Gávea, Rio de Janeiro, RJ, Brasil 22543-900.

E-mail: anicol@psi.puc-rio.br possível atingir interlocutores distantes instantaneamente. Assim sendo, tempo e espaço romperam a íntima associação que tradicionalmente haviam tido.

Bauman (2000/2001) e muitos outros autores (como Harvey, 1989/1999; Sennett, 1998/1999) registram essa mudança, que está na origem do período moderno. Bauman, em particular, o faz com muita acuidade. Diz: "A modernidade começa quando o espaço e o tempo são separados da prática da vida e entre si, e assim podem ser teorizados como categorias distintas e mutuamente independentes da estratégia e da ação..." (Bauman, 2000/2001, pp. 15-16). No período moderno, Bauman continua, tal separação teve como resultado o predomínio do tempo sobre o espaço, pois “... a modernidade é, talvez mais que qualquer outra coisa, a 'história do tempo'” (Bauman, 2000/2001, pp. 128-129).

Em meados da segunda metade do século XX, as concepções de tempo e espaço sofrem uma nova mudança. Esta é unanimemente registrada pelos autores da chamada corrente pós-modernista, pois é, segundo eles, um dos elementos que marcam o fim do período moderno (Bauman, 1997/1998, 2000/2001, 2001/2003; Sennett, 1998/1999; Harvey, 1989/1999, Jameson, 1984³ , 1991/1997; Virilio, 1984/1999; etc.). Nessa época, o avanço das tecnologias de telecomunicação (caracterizado primordialmente pela integração de diferentes pontos do mundo via satélite) permite que o capitalismo atinja um novo estágio - o da integração multinacional. Neste novo estágio, por sua vez, mesmo antes do "boom" das sofisticadas tecnologias da informação e

3 Essas primeiras idéias sobre a lógica cultural do capitalismo tardio foram re-impressas em Jameson (1991/1997). 
telecomunicação ocorrido na década de 1990, a aceleração limite do tempo, já atingida de forma restrita no período moderno, se alastra.

À semelhança do que acontece na esquizofrenia - patologia à qual alguns recorrem como modelo para a configuração subjetiva dos homens e mulheres de nossos dias (Jameson, 1991/1997) -, passamos a viver boas partes de nossas vidas em um eterno presente no qual temos experiências múltiplas e fragmentadas ${ }^{4}$. Nesse eterno presente, as noções de espaço se multiplicam, coexistem ${ }^{5}$, e ganham destaque.

É exatamente isso o que Jameson explicita na seguinte citação: “(...) penso que é possível argumentar (...) que a nossa vida cotidiana, nossas experiências psíquicas, nossas linguagens culturais são hoje dominadas pelas categorias de espaço e não pelas de tempo, como o eram no período anterior do alto modernismo" (Jameson, 1991/1997, p. 43).

Como conseqüência, grande importância passa a ser atribuída às concepções de espaço nos debates sobre as características da organização social de nossos dias. E as concepções contemporâneas de espaço não poderiam ser mais variadas e divergentes. Dado que também são freqüentemente inéditas, a dificuldade de estudá-las é tão grande que alguns autores chegam a se preocupar com a nossa - humana - incapacidade de pensar os novos espaços pelos quais transitamos e nos quais vivemos. Este é, por exemplo, o caso de Jameson e Augé.

Falando a respeito do que chama de "hiperespaço" pósmoderno, Jameson refere-se à "(...) incapacidade de nossas mentes (...) de mapear a enorme rede global e multinacional de comunicação descentrada em que nos encontramos presos como sujeitos individuais" (Jameson, 1991/1997, pp. 70-71). Já Augé (1992/2001) afirma que “(...) o mundo da supermodernidade não tem as dimensões exatas daquele no qual pensamos viver, pois vivemos num mundo que ainda não aprendemos a olhar. 'Temos que reaprender a pensar o espaço"” (Augé, 1992/2001, p. 37, minha ênfase).

O que se segue é um exercício desse processo de reaprendizagem. Para tanto, será feita uma revisão, forçosamente incompleta, da amplíssima e transdisciplinar literatura sobre os espaços contemporâneos.

Esta revisão será dividida em cinco partes cronologicamente organizadas (embora, em alguns casos haja algumas superposições de datas). A primeira discutirá, a partir do trabalho de Deleuze e Guattari (1980/1997), o uso de diferentes tipos: espaço como metáfora para diferentes tipos de organização e dinâmica sociais. A segunda abordará trabalhos "pós-modernistas" anteriores ao "boom" da difusão das redes digitais de informação e telecomunicação - como os de Jameson (1984, 1991/1997), Virilio (1984/1999), Harvey (1989/1999) e Augé (1992/2001) - que analisam as mudanças ocorridas no espaço físico ao longo das últimas décadas do século XX. Já a terceira parte se dedicará exclusivamente aos trabalhos de Bauman (1997/1998, 2000/2001, 2001/2003),

4 O que não está sujeito ao regime da temporalidade instantânea, passa a ser regido pelo curto prazo. Sennett (1998/1999) analisa a influência deste no trabalho, na vida em família, nos projetos de vida, etc.

5 Já em 1969, podíamos estar na nossa sala de estar e, ao mesmo tempo, nos juntar aos astronautas em seus primeiros passos na superfície da lua. outro autor da corrente pós-modernista que, por escrever após a vertiginosa difusão das tecnologias de informação e telecomunicação na década de 1990, passa a registrar a existência de espaços virtuais (embora ainda dê mais ênfase às alterações no espaço físico). Na quarta parte serão discutidas as concepções de espaços alternativos geradas pelo uso da Internet, tomando por base os trabalhos de Castells (1996/2000), Lévy (1990/1993), Wertheim (1999/2001) e vários outros autores. Por fim, a quinta parte abordará tanto as alterações no espaço físico quanto os espaços alternativos gerados pelo uso da telefonia celular a partir de inúmeros trabalhos recentes.

\section{O espaço como metáfora para diferentes tipos de organização e dinâmica sociais}

O trabalho precursor de Deleuze e Guattari (1980/1997) ocupa uma posição de destaque nas discussões sobre as mudanças sociais que deram origem à contemporaneidade. Por isso mesmo, a algumas das percepções e análises nele contidas será dedicada toda esta primeira parte do presente artigo. Passemos à sua exposição. Ainda em 1980 - e, portanto, muito antes do "boom" das tecnologias da informação e telecomunicação -, Deleuze e Guattari já detectam muitas características da contemporaneidade que somente mais tarde (principalmente na década de 1990) se tornam visíveis para outros autores. No quinto volume de Mil platôs: capitalimo e esquizofrenia (1980/1997), por exemplo, ao analisar as múltiplas facetas do novo capitalismo multinacional integrado e do processo de transformação das sociedades modernas (então em curso), esses autores identificam a importância dos arranjos espaciais como expressão das tensões entre os diferentes tipos de organização social envolvidos nessa transformação. Em conseqüência, usam duas metáforas espaciais para permitir sua visualização. Afirmam que as principais características da organização social contemporânea podem ser encapsuladas na metáfora de "espaço liso" enquanto que as da modernidade podem ser mais adequadamente cobertas pela metáfora de "espaço estriado".

Para Deleuze e Guattari, o espaço "estriado” se assemelha a um tecido com suas tramas de fios verticais e horizontais - alguns fixos e outros móveis - que se entrecruzam. É, portanto, emblemático da organização e do funcionamento sociais do sistema capitalista da era moderna, marcados que estes eram por certezas, barreiras, fronteiras e divisórias nítidas (entre espaços, áreas, saberes, etc.), bem como por processos seqüenciais e hierárquicos relativamente claros e firmemente estabelecidos. Já o espaço "liso", ainda de acordo com esses dois autores, se assemelha ao feltro, no qual não há distinção entre fios nem tampouco entrecruzamentos; há apenas um emaranhado de fibras. Este espaço não conhece certezas, demarcações, limites, fronteiras, centros, direções. "É infinito de direito, aberto ou ilimitado em todas as direções, não tem direito nem avesso, nem centro; não estabelece fixos e móveis, mas antes distribui uma variação contínua" (Deleuze \& Guattari, 1980/1997, p. 181). É, portanto, nômade e perfeito como metáfora para o período pós-moderno ou contemporâneo.

Esses dois tipos de espaço não se excluem mutuamente, apenas há o predomínio de um sobre o outro em determinados 
períodos. Do ponto de vista de Deleuze e Guattari, a organização social contemporânea é o resultado de um processo de alisamento pelo qual passou a sociedade moderna em função do capitalismo multinacional integrado, que eliminou boa parte (mas não todas) as suas estrias. Deleuze e Guattari têm ainda o mérito de identificar alguns aspectos distintivos desse processo de alisamento, que ainda eram embriônicos quando escreviam: a diluição de fronteiras e barreiras, a ausência de demarcações sociais, a crescente mobilidade de tudo e de todos, a desterritorialização, o nomadismo, a fluidez, etc. Embora esses aspectos sejam apenas apontados nas análises abstratas por eles efetuadas, exercem muita influência sobre os trabalhos de outros analistas da sociedade contemporânea que os sucedem, como é o caso dos pós-modernistas que serão discutidos a seguir.

\section{Alterações do espaço físico na literatura pós- moderna que antecede a revolução das tecnologias da informação e telecomunicação}

Poucos anos depois de Deleuze e Guattari tornarem pública sua metáfora do "espaço liso" como característica do período contemporâneo, Jameson e Virilio também revelam, embora de modos diferentes, o profundo impacto que a emergência do capitalismo multinacional integrado e o encolhimento do mundo neles havia gerado.

Jameson (1984, 1991/1997) discorre sobre um "hiperespaço" gerado pela "rede global e multinacional de comunicação descentrada" característica da pós-modernidade. Segundo ele, este hiperespaço é tão novo e multifacetado que "consegu[e] ultrapassar a capacidade do corpo humano de se localizar, de organizar perceptivamente o espaço circundante e mapear cognitivamente sua posição em um mundo exterior mapeável" (Jameson, 1991/1997, p. 70). Nesse espaço, passamos a viver experiências múltiplas e fragmentadas que, quando associadas ao já mencionado eterno presente característico do período, levam-no a afirmar que a esquizofrenia (desprovida de sua conotação patológica) é o modelo de funcionamento subjetivo da pós-modernidade ${ }^{6}$. Jameson, no entanto, se esquiva de descrever as características específicas desse hiperespaço em maior detalhe.

No mesmo ano de 1984 em que Jameson publica essas idéias pela primeira vez, Virilio também se dedica à discussão das novas mutações espaço-temporais do período pós-moderno e o faz de modo pouco sistemático e muito alarmista, pois vê nessas mutações a aniquilação não somente do tempo, mas também do espaço. Segundo ele, diversos tipos de "poluição" espaciais são geradas pela instantaneidade. A principal delas é aquela relativa ao encolhimento do mundo, que Virilio trata como a "poluição do tamanho natural que reduz a nada a escala, as dimensões terrestres" (Virilio, 1984/1999, p. 115). Sua visão apocalíptica a respeito da aniquilação do espaço é bastante clara na seguinte citação: “(...) se estar presente é estar próximo fisicamente falando, apostemos que a proximidade 'microfísica' das telecomunicações interativas fará com que amanhã nos ausentemos, não estejamos presentes para ninguém, encarcerados em um ambiente 'geofísico' reduzido a menos que nada”(Virilio, 1984/1999, p. 118).

6 Uma crítica a esta visão pode ser encontrada em Romão-Dias (2001).
Alguns anos após as publicações de Jameson e Virilio, Harvey (1989/1999) tece duras críticas à confusa e imprecisa "hiper-retórica" desses dois autores. Ao longo da análise que empreende da "condição pós-moderna", ele aprofunda a compreensão das concepções espaço-temporais que predominam no período pós-moderno e retoma alguns dos temas abordados por Deleuze e Guattari: a mobilidade, a desterritorialização, o nomadismo, etc. Seu trabalho, contudo, também é marcantemente diferente do desses dois últimos autores. Isso porque se volta para aspectos mais concretos da nova ordem social. Harvey dá especial ênfase ao que chama de "compressão do tempo-espaço", cujas origens históricas traça detalhadamente. Argumenta que esse tipo de compressão sempre esteve presente na ordem capitalista na medida em que esta sempre se caracterizou pela aceleração do ritmo da vida, ao mesmo tempo em que sempre venceu barreiras espaciais de modo a nos dar a sensação de progressivo encolhimento do mundo. Considerando apenas as tecnologias de telecomunicação disponíveis na época em que escreve (sistemas de comunicação por satélite, televisão, etc.), Harvey afirma que, na pós-modernidade, a instantaneidade tem como resultado a quase completa aniquilação dos obstáculos espaciais.

Interessado que está no sistema de produção e nas relações de trabalho, Harvey chama também a atenção para os diferentes graus de mobilidade "geográfica" de capitalistas e trabalhadores (Harvey, 1989/1999, p. 265). Enquanto os primeiros são altamente móveis (pois o capital desconhece fronteiras), os últimos sempre têm fortes raízes territoriais. Mais ou menos na mesma época em que Harvey publica essas análises, a mobilidade, também geográfica (ou seja, física), das pessoas em um mundo já integrado pelo capitalismo multinacional se torna o centro de atenções de Augé.

Augé (1992/2001) identifica um paradoxo. Afirma que, por um lado, tal como previam McLuhan e Powers (1986), o mundo encolheu na medida em que o espaço está sendo aniquilado pela velocidade e instantaneidade das diversas formas de transporte e telecomunicação atuais. Por outro lado, contudo, assevera que está havendo uma superabundância espacial. Esta, a seu ver, resulta principalmente das mudanças de escala a partir das quais tempo e espaço são medidos. Os meios de transporte são cada vez mais rápidos e aproximam lugares distantes em cada vez menos tempo; os satélites e espaçonaves conquistam o espaço ao redor da terra; as referências "energéticas e imaginárias" (Augé, 1992/2001, p. 36) - como, por exemplo, as imagens transmitidas por satélites que dão visão instantânea de acontecimentos distantes - se multiplicam. Essa superabundância espacial, por sua vez, gera consideráveis modificações físicas, como as transferências de população (migrações ou novas formas de nomadismo) e a proliferação de lugares que são tão diferentes dos lugares convencionais a ponto de por ele serem batizados de "não-lugares".

"Não-lugares" são, nas palavras do próprio Augé, aquelas "instalações necessárias à circulação das pessoas e bens (vias expressas, trevos rodoviários, aeroportos)" (Augé, 1992/2001, p. 36), os próprios meios de transporte, os grandes centros comerciais, os aeroportos, as rodoviárias, as redes de hotéis, etc. Em outras palavras, os "não-lugares" são aqueles espaços pelos quais circulam os nômades contemporâneos 
(todos aqueles que estão em trânsito). São anônimos e impessoais, mas têm referências globalmente significativas e globalmente compreensíveis (mesmas marcas de bebida, de comida, de redes de hotel, etc.). Augé tem, portanto, em comum com os demais autores discutidos nesta seção a percepção de que fronteiras e barreiras estão sendo aniquiladas, o que está tornando o mundo cada vez menor. Sua contribuição original reside na análise explícita da mobilidade geográfica e da emergência dos "não-lugares". A prefixação negativa indica que estes podem ser considerados um prenúncio dos lugares "extraterritoriais" sem definição positiva que estavam em vias de emergir no cenário das discussões dos espaços contemporâneos como resultado da difusão das redes digitais de transmissão de informação e telecomunicação em meados da década de 1990. A partir de então, intelectuais das mais diversas origens - sociólogos, filósofos, físicos, cientistas da computação e da telecomunicação, psicólogos, etc. - se vêem confrontados com o desafio de conceber e analisar a existência de espaços alternativos ao físico, espaços esses que não podem ser tratados apenas como boas metáforas ou descartados como simples obras da imaginação. O trabalho de Bauman (1997/1998, 2000/2001, 2001/2003), desenvolvido em uma fase posterior à difusão dessas novas tecnologias, deixa claro o quanto é difícil aceitar esse desafio.

\section{Bauman e o espaço gerado pelas redes digitais de informação e telecomunicação: a "bolha" extraterritorial desprovida de características próprias}

Apesar de escrever após o "boom" das redes digitais de informação e telecomunicação, Bauman (1997/1998, 2000/2001, 2001/2003) tem muita afinidade com os autores abordados na seção anterior, principalmente com Harvey e Augé, tanto porque sua argumentação retoma e dá sequiência à linha de raciocínio destes quanto porque, tal como eles, privilegia as alterações que ocorrem no espaço físico. A emergência de um espaço extraterritorial em função das tecnologias da informação e comunicação é por ele registrada, mas as características próprias deste espaço não são por ele analisadas (ou mesmo descritas com base no trabalho de autores como aqueles que serão discutidos na próxima parte).

Tal como Augé e Harvey, e também influenciado pelas idéias de Deleuze e Guattari, Bauman vê na diluição de fronteiras e barreiras e no encolhimento do mundo algumas das principais características de um novo período histórico. Este é por ele chamado de "pós-modernidade" em um primeiro momento (Bauman, 1997/1998), e de "modernidade líquida" (ou fluida) em um segundo (Bauman, 2000/2001). Dando concretude ao nomadismo detectado anos antes por Deleuze e Guattari, Bauman volta sua atenção para a mobilidade das pessoas neste novo mundo. Procura compreender a lógica espacial desse novo tipo de nomadismo. Para tanto, inspira-se nas concepções de Augé - principalmente na de não-lugares - e leva a cabo diversas análises das transformações do espaço físico na contemporaneidade. Sua principal linha de raciocínio é a seguinte.

A constante circulação de pessoas no mundo encolhido em que hoje vivemos vem fazendo com que estranhos se encontrem frente-a-frente. Estranhos, porém, são os depositários do medo em um mundo caracterizado pela incerteza das mudanças. Por esse motivo, passam a proliferar novos tipos de espaço físico nos quais estranhos podem evitar interagir. Esses espaços são o oposto dos espaços físicos convencionais (é interessante observar que Bauman, a exemplo de Augé, lhes dá nomes freqüentemente prefixados por "não" ou "extra"). Entre eles, os principais são os espaços públicos que Bauman chama de "não civis": os espaços "êmicos", como os guetos, que expulsam as pessoas; os espaços "fágicos", como os shoppings, que devoram as pessoas, lhes dão a sensação de segurança e facultam a sensação de pertencer a um novo tipo de comunidade sem a necessidade de interagir; os "nãolugares", como os saguões de aeroportos, que desencorajam a interação e a permanência prolongada; e os espaços "vazios", como bairros pobres e decadentes, cuja existência é ignorada e cujo atravessamento é evitado.

A circulação das pessoas no mundo líquido contemporâneo assume tanta importância para Bauman que este, a exemplo do que acontece com Harvey, a vê como uma das principais linhas divisórias da estratificação social contemporânea, embora a descreva de modo distinto em diferentes momentos de sua obra. Em O mal-estar da pós-modernidade (1998), fala da mobilidade diferencial de "turistas" (aqueles que se movem porque assim o desejam) e "vagabundos" (aqueles que são impelidos a se mover). Já em Modernidade líquida (2000/2001), isso muda na medida em que Bauman registra a existência de um espaço extraterritorial. A partir de então, Bauman passa a dividir a população mundial em dois grandes grupos em função de seu acesso ao novo espaço: o da elite global "dos negócios e da indústria cultural" (Bauman, 2000/2001, p. 55) e o da maioria assentada. A elite global detém o capital e o poder, agora tornados extraterritoriais. Para isso, conta com uma infra-estrutura tecnológica que é a condição de possibilidade de sua "extraterritorialidade". Na realidade, neste e em outros pontos de sua obra, Bauman afirma que essa elite passa a maior parte do tempo em uma "bolha", de modo a evitar compromissos e responsabilidades sociais geralmente associados a vínculos territoriais.

É interessante observar que Bauman (2000/2001, 2001/2003) atribui unicamente à elite cosmopolita global a propriedade de ser extraterritorial. Todos os demais parecem, portanto, fazer parte daquilo que chama de maioria assentada. Afirma textualmente que a "a irrelevância do lugar" - ou seja, a extraterritorialidade - é "uma condição inteiramente fora do alcance das pessoas comuns, dos 'nativos' estreitamente presos ao chão" (Bauman, 2000/2001, p. 54).

O próprio conceito de extraterritorialidade, como usado por Bauman, continua, no entanto, preso ao conceito de território. É como se, para Bauman, as pessoas ou aspectos da vida em sociedade ao perderem seus vínculos territoriais simplesmente se tornassem ausentes ou extraterritoriais. A "bolha" na qual circulam não recebe qualquer definição positiva, ou seja, não tem suas características próprias registradas. Ao atrelar a extraterritorialidade exclusivamente às elites mundiais, Bauman não parece poder conceber a existência de espaços de vida cotidiana, habitados por cidadãos comuns, que também não mantêm vínculos com o espaço físico tradicional. Outros, no entanto, vêem nessa mesma extraterritorialidade a possibilidade de geração de espaços alternativos de vida, dotados de características próprias e habitados por pessoas comuns. É o que veremos a seguir. 


\section{Espaços alternativos ao físico gerados pela Internet}

Para explorar as características próprias dos novos tipos de espaço extraterritorial gerados pela instantaneidade das tecnologias da informação e da telecomunicação (ou seja, para conhecer o que são e não o que não são), é útil recorrer ao artifício de separá-los de acordo com os equipamentos mais freqüentemente usados para a eles facultar acesso: os computadores e congêneres (laptops, palmtops, etc.) e os celulares. Nesta quarta parte serão discutidos os espaços que têm nos computadores internacionalmente ligados em rede sua plataforma de acesso, na quinta parte serão discutidos aqueles cuja plataforma são os celulares.

\section{Espaço dos fluxos}

Dentre os diversos autores que examinam as alternativas espaciais geradas pelas novas tecnologias da informação e telecomunicação são poucos aqueles que se dedicam à análise da sociedade contemporânea como um todo. Um deles é Castells (1996/2000).

Sendo sociólogo, Castells tem, tal como Harvey e Bauman, particular interesse nas novas formas de organização social e na sua dinâmica. Diferentemente destes dois autores, porém, vê essas novas formas não como um desenvolvimento tardio do capitalismo cuja infra-estrutura é dada pelas novas tecnologias da informação (microeletrônica, computação, telecomunicações/radiodifusão, optoeletrônica, etc.), mas como um produto da convergência dessas tecnologias.

Esta concepção de que diversas tecnologias convergem para gerar a forma material de suporte dos processos e funções dominantes na sociedade informacional é exatamente o que leva Castells a propor a definição mais abrangente de espaço alternativo encontrada na literatura, a de espaço dos fluxos. Ele afirma:

\footnotetext{
“' O espaço dos fluxos é a organização material das práticas sociais de tempo compartilhado que funcionam por meio de fluxos'. Por fluxos, entendo as seqüências intencionais, repetitivas e programáveis de intercâmbio e interação entre posições fisicamente desarticuladas, mantidas por atores sociais nas estruturas econômica, política e simbólica da sociedade." (Castells, 1996/2000, pp. 436-437, ênfase do autor)
}

Trocando em miúdos, no entender de Castells, o espaço dos fluxos domina e molda a nova organização social contemporânea, a da "sociedade em rede".

Embora os suportes materiais desse espaço sejam constituídos pela convergência de tecnologias que servem de infra-estrutura tanto à rede internacional de computadores quanto à telefonia celular, Castells concentra sua análise no espaço gerado pela Internet.

Enfatiza a autonomia de que o espaço dos fluxos desfruta em relação às leis da física e, tal como Harvey e Bauman, assinala que a ele nem todos têm acesso. Fala a respeito de uma "divisória digital", mas discorda daqueles que acreditam que a Internet está criando um mundo dividido entre os que têm e os que não têm acesso a ela. Embora concorde com a observação de que aqueles que a ela não têm acesso perdem competitividade no mercado de trabalho (indivíduos) ou no mercado internacional (empresas, nações), acredita que essa desigualdade é anterior à Internet, sendo fruto das diferenças há muito existentes na origem social, no nível cultural e no nível de educação das populações (Castells, 2000/2003). Não se aprofunda, contudo, nas discussões das formas de vida possíveis no espaço dos fluxos e não aborda a telefonia celular.

\section{Ciberespaço}

Embora a definição que Castells dá ao espaço alternativo gerado pela convergência das tecnologias da informação e telecomunicação seja a mais abrangente, a nomenclatura mais difundida para fazer referência ao espaço virtual criado pela conexão em rede dos computadores mundiais é a de ciberespaço.

Usado pela primeira vez em Neuromancer, uma obra de ficção científica escrita por William Gibson (1984), ciberespaço tem uma de suas definições básicas dada por Crumlish (1995). Para este, ciberespaço é o espaço no qual é compartilhada a realidade imaginária criada pelas redes de computadores. É, portanto, um espaço autônomo, pois " $O$ ciberdomínio não é feito de forças e partículas físicas, mas de bits e bytes" (Wertheim, 1999/2001, p. 167) e, por isso mesmo, não está sujeito às leis da física.

Para Lévy (1990/1993), um de seus mais conhecidos analistas, Internet e ciberespaço são a mesma coisa. Tal equação o leva a afirmar que a Internet "não está no espaço, "ela é o espaço" (Lévy, 1990/1993, p. 26, minha ênfase). E mais, diferentemente de Bauman, para quem, como já foi discutido, somente a elite global tem acesso à extraterritorialidade, Lévy enfatiza o fato de que o ciberespaço é um terreno no qual está vivendo a humanidade hoje.

E o que acontece nesse espaço? Por ele circulam a informação e os bens imateriais. Como já foi mencionado, nele são também implementadas novas formas de vigilância, controle e poder. Mas isso não é tudo. Segundo diversos autores (Lévy, 1990/1993; Castells, 1996/2000; Rheingold, 1993, etc.), o ciberespaço também é o espaço no qual são colocadas em prática diferentes formas e manifestações de solidariedade, de coesão social, de resistência, de movimentos políticos, de vida comunitária, etc. É, ainda, segundo outros autores (Turkle, 1995; Nicolaci-da-Costa, 1998; Leitão \& Nicolacida-Costa, 2000; Abreu \& Nicolaci-da-Costa, 2003; etc.), um espaço que se tornou o palco (imaginário mas vivido como real) de novas formas de vida que abrangem praticamente todas as áreas do nosso cotidiano: trabalho, educação, lazer, informação, conversas intelectuais, bate-papos informais, sedução, paquera, namoro, solidariedade, etc.

Essas diversas formas de vida foram tornadas possíveis por uma importante característica deste espaço alternativo: sua qualidade de ser imersivo. Em outras palavras, diferentemente do caso de outras tecnologias de ponta, como a dos celulares que será discutida abaixo, essas formas alternativas de vida foram tornadas possíveis pelo fato de que se pode ficar on line o tempo que se desejar (respeitadas somente as restrições e necessidades corporais dos usuários) ${ }^{7}$.

7 Na realidade, nos primeiros tempos de acesso ao ciberespaço, foi tão alto o número usuários que começaram a passar boas partes de seus dias on line que muitos julgaram haver detectado uma nova forma de patologia: a do vício na Internet (ver Nicolaci-da-Costa, 2002a) 


\section{Espaços gerados pela telefonia celular}

Como podemos depreender da breve discussão desenvolvida acima, as características do ciberespaço bem como muitas de suas consequiências sociais e pessoais já vêm sendo investigadas por muitos estudiosos de origens disciplinares diversas. O mesmo, no entanto, não acontece com a telefonia celular. E há algumas razões para isso.

Primeiramente, os celulares são ainda muito recentes e as investigações de seus impactos começaram a se tornar acessíveis principalmente a partir do ano de 2002. Em segundo lugar, muitas das características do ciberespaço são incorporadas pelos celulares, incorporação essa que é particularmente observável no caso do Japão onde a Internet é acessada principalmente a partir dos celulares (Rheingold, 2003; Gottlieb $\&$ McLelland, 2003). Uma terceira razão para a escassez de estudos sobre as alterações que os celulares vêm introduzindo nos espaços convencionais e as alternativas a estes que criam é a de que os celulares não parecem gerar novos espaços. Isso porque, diferentemente dos computadores (e até mesmo dos laptops e palmtops), suas pequenas dimensões e o ainda alto custo das ligações não possibilitam a imersão prolongada do usuário em um espaço alternativo.

Desse modo, as análises tendem a se concentrar na forma mais freqüente de uso dos celulares: a da comunicação breve, porém constante, que enfatiza seu poder de conectar diferentes pontos do espaço físico, mas ofusca a sua propriedade de gerar novos espaços.

\section{A conectividade e a fluidificação do espaço físico}

A principal característica da telefonia celular é certamente a sua capacidade de conectar em "tempo real", ou instantaneamente, diferentes pontos do espaço físico independentemente da mobilidade dos interlocutores e/ou da distância que os separa.

Esta capacidade tem importantes conseqüências para a vida pessoal e social de seus usuários. Pesquisas realizadas na Noruega (Ling \& Yttri, 2002; Ling, 2004), e na Finlândia (Mäenpäa, 2001; Kopomaa, 2000), destacam uma dessas conseqüências: a capacidade de micro-coordenação de atividades, encontros e compromissos. Seus autores afirmam que, com o uso de sistemas de comunicação móveis, não mais necessitamos fazer arranjos para nos encontrarmos em determinados lugares e horários pré-fixados. Encontros se tornaram ajustáveis ao fluxo dos acontecimentos cotidianos. O mesmo tipo de flexibilização de encontros e compromissos parece acontecer em muitos outros lugares do mundo, entre os quais estão países tão diversos quanto o Japão, o Brasil, a Coréia e a Itália.

No Japão, Ito e Okabe (2003) observam que os horários dos compromissos e encontros dos jovens se tornou mais fluido na medida em que estes estão sempre em contato uns com os outros, geralmente via mensagens de texto que são consideradas pouco intrusivas pela cultura japonesa. No Brasil, também trabalhando com jovens, Nicolaci-da-Costa (2004a, 2004b) constata que, de modo parecido ao que acontece com os jovens japoneses, eles tendem a "ir se falando" para combinar encontros ou alterar combinações previamente feitas. A diferença corre por conta do fato de que os jovens brasileiros realmente "se falam", ou seja, usam contato de voz. Na Coréia, Kim (2002) registra a importância que os celulares passaram a ter na manutenção da vida social numa cultura na qual a expectativa é a de que a sociabilidade deve acontecer espontaneamente. Fortunati (2002) relata que o mesmo acontece na Itália, onde os celulares são geralmente vistos como facilitadores das relações sociais na medida em que a programação prévia de encontros interpessoais tende a ser culturalmente mal vista em vários setores da sociedade italiana.

Todas essas formas de micro-coordenação pressupõem aquilo a que Katz e Aakhus (2002) se referem como o potencial de "contato perpétuo" da telefonia celular, ou seja, esses modos de micro-coordenação pressupõem que todos os eventuais interlocutores têm sempre seus celulares perto de si e ligados.

Nos dias de hoje, esta pressuposição é confirmada para enormes percentuais das populações mundiais ${ }^{8}$. Uma inspeção dos diversos artigos de diferentes nacionalidades compilados por Katz e Aakhus (2002) mostra que, nas mais diversas partes do mundo, alguém se movimentar carregando consigo um celular se tornou um comportamento trivial.

O contato perpétuo gerado pela conectividade dos celulares tem ainda duas outras consequiências inter-relacionadas, que são bastante relevantes para uma discussão das novas noções de espaço na contemporaneidade: a emergência de um novo tipo de nomadismo e a criação de uma rede social móvel.

As operadoras de telefonia celular enfatizam que podemos viver em um mundo sem fronteiras ou barreiras. Ao menos em princípio (porque nem sempre tudo funciona assim), podemos nos comunicar com quem quisermos a partir de qualquer lugar e a qualquer hora do dia e da noite sem nos preocuparmos com onde está o nosso interlocutor. Tanto faz que ele esteja na sala ao lado ou em algum ponto geograficamente bastante distante. Essa característica, que, como vimos anteriormente, Bauman (2000/2001) batizou de "irrelevância do lugar", faz com que potenciais interlocutores estejam constantemente em movimento, mas sempre disponíveis para um contato, uma conversa, uma interação, etc.

Tornou-se muito fácil falar com os amigos, conhecidos, familiares, colegas, etc. Na maior parte das vezes, basta acionar poucas teclas. Isso porque aqueles que conhecemos geralmente têm seus números armazenados na própria memória do nosso celular. Dito de outro modo e fazendo uso de uma metáfora mundana, os celulares funcionam como uma espécie de mochila na qual carregamos a nossa rede social, que se tornou móvel. Todos os números que chamamos com freqüência e muitos daqueles que contatamos raramente no mais das vezes encontram-se armazenados na memória dos nossos celulares, memória essa que os fabricantes tornam progressivamente maior (Nicolaci-da-Costa, 2004a).

Em resumo, não precisamos mais estar em algum lugar conhecido para que possamos ser alcançados e também não

8 No caso dos celulares, não há o problema da exclusão das camadas de baixa renda ou de amplos setores dos países em desenvolvimento. Isso porque os aparelhos são relativamente baratos e a telefonia celular independe da infra-estrutura física muitas vezes inexistente em certos lugares. 
precisamos saber onde estão nossos parentes, amigos ou conhecidos para que com eles possamos entrar em contato. Podemos nos movimentar sem o receio de não sermos alcançados. Podemos fluir por um espaço híbrido, um espaço físico que pode a qualquer momento ser interrompido por comunicações virtuais. Sem que disso muitos de nós tenhamos nos dado conta, tornamo-nos nômades e o espaço físico que habitamos e pelo qual transitamos se tornou fluido em virtude da comunicação virtual.

Esta é a materialização do espaço liso de Deleuze e Guattari (1980/1997) ou da fluidez que Bauman (2000/2001) diz caracterizar a modernidade líquida.

\section{Redefinições dos espaços públicos e privados}

Se, para que a comunicação aconteça, nós e nossos potenciais interlocutores não mais temos que estar em lugares fixos e conhecidos (como na época da telefonia fixa), e se tanto eles como nós podemos ligar de qualquer lugar ou sermos alcançados não importa onde estejamos, as chances são grandes de que muitas comunicações ocorram enquanto estamos em lugares públicos: condução, aulas, supermercados, praias, igrejas, etc. Essa penetração dos espaços públicos por um espaço privado virtual (espaço esse que será discutido em maiores detalhes abaixo) vem gerando muita discussão acalorada.

Rheingold (2003), um dos pioneiros no estudo dos impactos sociais da telefonia celular registra de forma clara as transformações que espaço público vem sofrendo:

\footnotetext{
"Dado que cada vez mais pessoas nas ruas das cidades e no transporte público passam cada vez mais tempo falando com outras pessoas que não estão fisicamente co-presentes, a natureza dos espaços públicos... está mudando diante dos nossos próprios olhos e ouvidos..." (Rheingold, 2003, p. xxii, minha tradução)
}

$\mathrm{Na}$ realidade, praticamente todos os autores que investigam a penetração dos celulares nas sociedades contemporâneas discutem essas transformações. Alguns, a exemplo de Fortunati (2002), o fazem a partir de um ponto de vista negativo - vendo com maus olhos o que chama de disrupção tanto dos espaços públicos (nos quais os circundantes são obrigados a ouvir as conversas privadas de desconhecidos) quanto dos contatos face-a-face (nos quais a conversa presencial é interrompida e um ou mais dos interlocutores fisicamente presentes são preteridos por interlocutores distantes). Em contraparatida, outros acolhem positivamente a interrupção de grande parte das conversas face-a-face. Um exemplo é Gergen (2002), cujo argumento é o de que os celulares são importantes na manutenção dos laços endógenos (aqueles existentes entre os membros do grupo de parentes e pessoas íntimas) e que as interrupções dos contatos face-a-face exógenos (com estranhos ou conhecidos superficiais) indicam que nosso tempo de comunicação é progressivamente dedicado àqueles que realmente contam para nós.

Outros ainda, como Puro (2002) e Ling (2004), adotam uma abordagem semelhante àquela de Rheingold citada acima, ou seja, menos valorativa e mais descritiva. Para Puro, " $o$ espaço público é duplamente privatizado porque os usuários de celulares se isolam de modo não-verbal e enchem o ar com assuntos privados" (Puro, 2002, p. 23). A visão de Ling (2004) também é predominantemente descritiva. Ressalta o aspecto de comunicação paralela da telefonia celular e afirma que os celulares tornam possível a colonização da esfera pública para interações pessoais (Ling, 2004) sem maiores julgamentos de valor.

Alguns outros autores, a exemplo de Shejter e Cohen (2002) e Ito e Okabe (2003) fornecem interessantes indicadores da reação negativa gerada em determinadas populações pelo fenômeno da penetração dos espaços públicos pelas conversas telefônicas privadas. Relatam, por exemplo, que em países como Israel e o Japão há cartazes proibindo o uso de celulares em diversos locais públicos.

A outra face da mesma moeda é a penetração da esfera pública no espaço privado (Fortunati, 2002). A literatura especializada dá, porém, pouca ênfase a esse tipo de penetração como conseqüência da difusão dos celulares. Isso talvez se deva ao fato de que é menos freqüente no caso de seus usuários mais estudados: os jovens.

\section{A emergência de espaços privados móveis}

Como acabamos de ver, muitos falam sobre a invasão dos espaços públicos por conversas privadas com pessoas distantes. Subentendida fica, portanto, a existência de espaços privados que interferem no espaço público. Relativamente poucos, no entanto, se dedicam a estudar esse novo tipo de espaço em maior profundidade.

Ao fazê-lo, alguns deles se referem ao celular como um "lugar". Puro, por exemplo, afirma que "um telefone móvel é, em muitos aspectos, um lugar ao qual você pode ir para bater papo sobre qualquer assunto" (Puro, 2002, p. 27). Isso porque, "quando alguém fala ao telefone, esse alguém está em seu próprio espaço privado" (Puro, 2002, p.23). Já segundo Kopomaa (2000), o celular pode ser visto um "terceiro lugar", ou seja, como um "lugar" adjacente, porém fora do espaço doméstico ou do trabalho. Tal como para Puro, também para Kopomaa o celular é, a seu próprio modo, um "lugar" de encontros na medida em que oferece um espaço virtual para o qual qualquer um pode se retirar quando desejar.

Ito e Okabe (2003) dizem o mesmo com palavras diferentes. Referem-se a esses lugares como "espaços virtuais móveis". Seus estudos revelam o quanto estes espaços alternativos são importantes para a manutenção da privacidade entre jovens japoneses que dispõem de pouco espaço físico privado, pois suas moradias são pequenas e frequientemente habitadas por muitos membros da família. McVeigh (2003), que também trabalha com jovens estudantes japoneses, chega à mesma conclusão e dá mais um passo no sentido da apreensão de uma outra importante dimensão dos impactos do uso dos celulares sobre pelo menos alguns de seus usuários: a dimensão psicológica. Relata que, em sua pesquisa, muitos estudantes falaram do espaço privado que os celulares lhes proporcionaram como se esses aparelhos criassem um mundo à parte para eles ou aumentasse sua interioridade psicológica (McVeigh, 2003). Em um contexto bem distante e bastante diferente, Nicolaci-da-Costa (2004a) mostra como o mesmo acontece com jovens universitários cariocas. Estes 
vêem nos celulares uma oportunidade de ter um "espaço privado" precoce por padrões tradicionais. Tal espaço, por exemplo, permite que esses jovens mantenham seus relacionamentos (principalmente os amorosos) longe dos olhos e dos ouvidos de seus pais mesmo quando moram com estes. E mais, independentemente de onde estejam eles próprios e seus interlocutores, permite que eles mantenham contato constante ao longo do dia elou da noite com seus amigos íntimos e namorados. Muitos chegam a ter consciência de que a constante utilização desses "espaços privados móveis" aumenta a intimidade dos relacionamentos.

A análise que Gergen (2002) faz dos "mundos flutuantes" da "presença ausente" mediada pelos celulares complementa essas observações. Tal como Kopomaa, Ito e Okabe, Nicolaci-da-Costa e outros, Gergen afirma que esses mundos flutuantes pouco têm a ver com o que está acontecendo ao redor do interlocutor no mundo físico. $\mathrm{E}$, tal como McVeigh e Nicolaci-da-Costa, Gergen declara que, muito ao contrário do que pensam alguns autores proeminentes (entre os quais os sociólogos Bauman, 1997/1998, 2000/2001, 2001/2003 e Sennett, 1998/1999), a presença ausente é uma extensão dos relacionamentos face-a-face que fortalece os laços sociais endógenos (ou seja, íntimos), quando todos estão em constante movimento e, portanto, freqüentemente distantes uns dos outros. Esta posição é reforçada e radicalizada por de Gournay (2002), que chega a falar que os celulares permitem uma relação "fusional" com pessoas íntimas na medida em que "Levamos uma parte da outra pessoa conosco, certos da sua disponibilidade para a posse permanente e total" (de Gournay, 2002, p. 201, minha tradução).

\section{Conclusão}

Ao longo do século XIX, em decorrência da implantação dos primeiros parques industriais em áreas adjacentes às cidades da época, surge um novo tipo de espaço: aquele das grandes metrópoles. No início do século XX, no célebre artigo intitulado A metrópole e a vida mental, Simmel (1902/1997) dedica-se à análise das consequiências psicológicas da vida nesse novo espaço. Tal análise o leva a lançar as bases do que hoje se entende como a construção social da subjetividade. Diz:

“(...) de cada ponto da superfície da experiência (...) pode-se deixar cair um fio de prumo para o interior da profundeza do psiquismo, de tal modo que todas as exterioridades mais banais da vida estão, em última análise, ligadas às decisões concernentes ao significado e estilo de vida." (Simmel, 1902/1997, p. 15)

A partir desse raciocínio, Simmel demonstra com clareza que novos espaços colocam em operação novas necessidades, novas demandas, novas regras de produção, sociabilidade, sobrevivência, etc. Como consequiência de tudo isso, emergem novas formas de agir e de viver que dão visibilidade aos processos de transformação das formas de ser (Nicolaci-daCosta, 2002b).

Transposto para o início do século XXI, este raciocínio resulta na colocação imediata de duas perguntas do ponto de vista da psicologia. A primeira é: Quais os impactos que cada um dos vários espaços discutidos neste artigo está gerando? Para esta, já existem respostas parciais, muitas das quais (como os efeitos da vida no ciberespaço e do uso dos celulares como espaços privados móveis) foram apresentadas neste artigo.

Já para a segunda pergunta, que é mais espinhosa, a(s) resposta(s) só pode(m) ser dada(s) uma vez que seja reconhecido, como aconteceu na presente revisão, que estamos vivendo em múltiplos espaços. Essa pergunta poderia ser formulada do seguinte modo: Quais os impactos que a vida em diferentes espaços físicos e virtuais está gerando em todos nós? Para respondê-la são necessárias mais pesquisas e muita reflexão.

\section{Referências}

Abreu, R. S. \& Nicolaci-da-Costa, A. M. (2003). Internet: um novo desafio para os educadores. Cadernos de Psicologia e Educação Paidéia, 13(25), 27-40.

Augé, M. (2001). Não-lugares: introdução a uma antropologia da supermodernidade. (M. P. Pereira, Trad.) Campinas: Papirus. (Trabalho original publicado em 1992)

Bauman, Z. (1998). O mal-estar da pós-modernidade. (M. Gama \& C. M. Gama, Trads.) Rio de Janeiro: Jorge Zahar. (Trabalho original publicado em 1997)

Bauman, Z. (2001). Modernidade líquida. (P. Dentzien, Trad.) Rio de Janeiro: Jorge Zahar. (Trabalho original publicado em 2000)

Bauman, Z. (2003). Comunidade. (P. Dentzien, Trad.) Rio de Janeiro: Jorge Zahar. (Trabalho original publicado em 2001)

Castells, M. (2000). A sociedade em Rede. (R. V. Majer, Trad.) São Paulo: Paz e Terra. (Trabalho original publicado em 1996)

Castells, M. (2003). Internet e sociedade em rede. Em D. de Moraes (Org.), Por uma outra comunicação: mídia, mundialização cultural e poder (pp. 255-287). Rio de Janeiro: Record. (Trabalho original publicado em 2000)

Crumlish (1995). The Internet dictionary. Nova York: Sybex.

de Gournay, C. (2002). Pretense of intimacy in France. Em J. E. Katz \& M. Aakhus (Orgs.), Perpetual contact: mobile communication, private talk, public performance (pp. 193-205). Cambridge: Cambridge University Press.

Deleuze, G. \& Guattari, F. (1997). Mil platôs: capitalismo e esquizofrenia, volume 5. (P. P. Pelbart \& J. Caiafa, Trads.) São Paulo: Editora 34. (Trabalho original publicado em 1980)

Fortunati, L. (2002). Italy: stereotypes, true and false. Em J. E. Katz \& M. Aakhus (Orgs.), Perpetual contact: mobile communication, private talk, public performance (pp. 42-62). Cambridge: Cambridge University Press.

Gergen, iniciais (2002), The challenge of absent presence. Em J. E. Katz \& M. Aakhus (Orgs.), Perpetual contact: mobile communication, private talk, public performance (pp. 227-241). Cambridge: Cambridge University Press.

Gibson, W. (1984). Neuromancer. Berkeley: Ace.

Gottlieb, N. \& McLelland, M. (2003). The Internet in Japan. Em N. Gottlieb \& M. McLelland (Orgs.), Japanese cybercultures (pp. 1-16). Londres: Routledge.

Harvey, D. (1999). Condição pós-moderna. (A. U. Sobral \& M. S. Gonçalves, Trads.) Rio de Janeiro, Loyola. (Trabalho original publicado em 1989)

Ito, M. \& Okabe, D. (2003). Mobile phones, Japanese youth and the re-placement of social contact. Retirado em 11/12/2003 http://www.itofisher.com/PEOPLE/mito/mobileyouth.pdf. 
Jameson, F. (1984). Postmodernism, or the cultural logic of late capitalism. New Left Review, 146, pp. 53-92.

Jameson, F. (1997). Pós-modernismo: a lógica cultural do capitalismo tardio. (M. E. Cevasco, Trad.) São Paulo: Ática. (Trabalho original publicado em 1991)

Katz, J. E. \& Aakhus, M. (2002). Introduction: framing the issues. Em J. E. Katz \& M. Aakhus (Orgs.), Perpetual contact: mobile communication, private talk, public performance (pp. 1-13). Cambridge: Cambridge University Press.

Kim, S. D. (2002). Korea: personal meanings. Em J. E. Katz \& M. Aakhus (Orgs.), Perpetual contact: mobile communication, private talk, public performance (pp. 63-79). Cambridge: Cambridge University Press.

Kopomaa, T. (2000). Speaking mobile: the city in your pocket. Helsinki: Gaudeamus.

Leitão, C. \& Nicolaci-da-Costa, A. M. (2000). Psicologia clínica e informática: por que essa inusitada aproximação? Psicologia Clínica, 12(2), 189-205.

Lévy, P. (1993). As tecnologias da inteligência: o futuro do pensamento da era da informática. (C. I. Costa, Trad.) Rio de Janeiro, Editora 34. (Trabalho original publicado em 1990)

Ling, R. (2004). The mobile connection: The cell phone's impact on society. San Francisco: Morgan Kaufmann.

Ling, R. \& Yttri, B. (2002). Hyper-coordination via mobile phones in Norway. Em J. E. Katz \& M. Aakhus (Orgs.), Perpetual contact: mobile communication, private talk, public performance (pp. 139-169). Cambridge: Cambridge University Press.

Mäenpäa, P. (2001). Mobile communication as a way of urban life. Em A. Warde \& J. Gronow (Orgs.), Ordinary consumption (pp. 107-123). Londres: Routledge.

McLuhan, M. \& Powers, B. (1986). The global village: transformations in world life and media in the $21^{\text {st }}$ century. Nova York: Oxford University Press.

McVeigh, B. J. (2003). Individualization, individuality, interiority, and the Internet: Japanese university students and e-mail. Em N. Gottlieb \& M. McLelland (Orgs.), Japanese cybercultures (pp. 19-33). Londres: Routledge.

Nicolaci-da-Costa, A.M. (1998). Na malha da Rede: Os impactos intimos da Internet. Rio de Janeiro: Campus.

Nicolaci-da-Costa, A. M. (2002a). Internet: a negatividade do discurso da mídia versus a positividade da experiência pessoal. À qual dar crédito? Estudos de Psicologia (UFRN), 7(1), 2535.

Nicolaci-da-Costa, A. M. (2002b). Revoluções tecnológicas e transformações subjetivas. Psicologia: Teoria e Pesquisa, 18(2), 193-202.
Nicolaci-da-Costa, A. M. (2004a). Impactos psicológicos do uso de celulares: uma pesquisa exploratória com jovens brasileiros. Psicologia: Teoria e Pesquisa, 20(2), 165-174.

Nicolaci-da-Costa, A. M. (2004b). A passagem interna da modernidade para a pós-modernidade. Psicologia: Ciência e Profissão, 24(1), 82-93.

Puro, J. P. (2002). Finland: a mobile culture. Em J. E. Katz \& M. Aakhus (Orgs.), Perpetual contact: mobile communication, private talk, public performance (pp. 19-29). Cambridge: Cambridge University Press.

Rheingold, H. (1993). The virtual community: Homesteading on the electronic frontier. Retirado em 12/04/2002 http://www. well.com/user/hlr/vcbook/.

Rheingold, H. (2003). Smart mobs: the next social revolution. Cambridge, Mass.: Perseus Books.

Romão-Dias, D. (2001). Nossa plural realidade: um estudo sobre a subjetividade na era da Internet. Dissertação de Mestrado, Pontifícia Universidade Católica do Rio de Janeiro, Rio de Janeiro.

Sennett, R. (1999). A corrosão do caráter: conseqüências pessoais do trabalho no novo capitalismo. (M. Santarrita, Trad.) Rio de Janeiro: Record. (Trabalho original publicado em 1998)

Simmel, G. (1987). A metrópole e a vida mental. Em O. G. Velho (Org.), Ofenômeno urbano (pp. 11-25). Rio de Janeiro: Editora Guanabara, 1987. (Trabalho original publicado em 1902)

Shejter, A. \& Cohen, A. (2002). Israel: chutzpah and chatter in the Holy Land. Em J. E. Katz \& M. Aakhus (Orgs.), Perpetual contact: mobile communication, private talk, public performance (pp. 30-41). Cambridge: Cambridge University Press.

Turkle, S. (1995). Life on Screen: identity in the age of the Internet. Nova York: Touchstone.

Virilio, P. (1999). Espaço crítico. (P. R. Pires, Trad.) Rio de Janeiro, Editora 34. (Trabalho original publicado em 1984)

Wertheim, M. (2001). Uma história do espaço de Dante à Internet (M. L. X. A. Borges, Trad.) Rio de Janeiro: Jorge Zahar. (Trabalho original publicado em 1999)

Recebido em 12.05.2005

Primeira decisão editorial em 28.06.2005

Versão final em 28.06.2005

Aceito em 12.12.2005 